Dominika Kostrzewa

kostrzewa.dominika@wp.pl

orcid.org/0000-0002-6594-8658

Uniwersytet Gdański

Katedra Teorii i Filozofii Państwa i Prawa

ul. Jana Bażyńskiego 6

80-309 Gdańsk

\title{
Kompetencje organu konserwatorskiego do wydania decyzji na podstawie art. 45 ust. 1 ustawy o ochronie zabytków i opiece nad zabytkami a wpis do rejestru - analiza przypadku
}

The Competence of a Conservation Body to Issue a Construction Permit Based on Law Amending the Act on the Protection of Monuments and the Guardianship of Monuments, Article 45, Section 1 versus a Determination of Monument Status - A Case Study

Summary: The II OSK $3 / 15$ verdict of the Polish Supreme Administrative Court, dated 18 October 2016, is concerned with the Law Amending the Act on the Protection of Monuments and the Guardianship of Monuments, Article 36, Section 1, Clause 1; and Article 45, Section 1 , Clause 1 and 2.

In its verdict of 18 October 2016, the Supreme Administrative Court clearly indicated the consequences of registering a building as a monument even after the prior issue of a construction permit and commencement of construction work on the property. The court further pointed out the conservation body's lack of a proper analysis of the problem in their justification. The Building Code, Article 39, Section 1, and the Law Amending the Act on the Protection of Mon- 
uments and the Guardianship of Monuments, Article 36, Section 1, Clause 1 , cannot be the basis for ruling out the conservator's actions in the situation described in this verdict.

The Supreme Administrative Court clearly emphasised that undertaking construction work according to a valid construction permit does not negate the competence of a conservation body to issue a decision based on the Law Amending the Act on the Protection of Monuments and the Guardianship of Monuments, Article 45, Section 1, even if the property was included in the National Register of Historical Monuments after the relevant construction permit was issued. As soon as a building is added to the register, an investor is obligated to obtain a conservation permit, as mentioned in Article 36, Section 1 , Clause 1 of the previously mentioned act.

Keywords: construction permit, monument registration, conservation body, construction work, conservation permit

Streszczenie: Wyrok Naczelnego Sądu Administracyjnego z dnia 18 października 2016 r. (sygn. akt II OSK 3/15) dotyczy art. 36 ust. 1 pkt 1 i art. 45 ust. 1 pkt 1 i 2 ustawy o ochronie zabytków i opiece nad zabytkami. Naczelny Sąd Administracyjny w omawianym wyroku prawidłowo wskazał skutki wpisu do rejestru zabytku, nawet gdy miał on miejsce po wydaniu decyzji o pozwolenie na prowadzenie robót budowlanych przy nieruchomości. Zwrócił też uwagę na problem braku dokładniej analizy zagadnienia w uzasadnienia decyzji ze strony organów konserwatorskich. Artykuł 39 ust. 1 Prawa budowlanego w zestawieniu z art. 36 ust. 1 pkt 1 ustawy o ochronie zabytków i opiece nad zabytkami nie stanowi wykluczenia dla działań konserwatora zabytków w tej sytuacji. Naczelny Sąd Administracyjny wyraźnie zaznaczył, że prowadzenie robót budowlanych na podstawie decyzji o pozwoleniu na budowę nie wyłącza kompetencji organu konserwatorskiego do wydania decyzji na podstawie art. 45 ust. 1 ustawy o ochronie zabytków i opiece nad zabytkami, gdy zabytek nieruchomy został wpisany do rejestru zabytków po wydaniu decyzji o pozwoleniu na prowadzenie przy tej nieruchomości robót budowlanych. Z datą wpisania nieruchomości do rejestru zabytków na inwestorze spoczywa bowiem obowiązek uzyskania pozwolenia konserwatorskiego, o którym mowa w art. 36 ust. 1 pkt 1 tej ustawy.

Słowa kluczowe: decyzja o pozwoleniu na budowę, rejestr zabytków, organy konserwatorskie, roboty budowlane, pozwolenie konserwatorskie 


\title{
Teza wyroku Naczelnego Sądu Administracyjnego z dnia 18 października 2016 r., sygn. akt II OSK 3/15
}

\begin{abstract}
Prowadzenie robót budowlanych w oparciu o decyzję o pozwoleniu na budowę nie wyłącza kompetencji organu konserwatorskiego do wydania decyzji na podstawie art. 45 ust. 1 ustawy o ochronie zabytków i opiece nad zabytkami, gdy zabytek nieruchomy został wpisany do rejestru zabytków po wydaniu decyzji o pozwoleniu na prowadzenie przy tej nieruchomości robót budowlanych. Z datą wpisania nieruchomości do rejestru zabytków, na inwestorze spoczywa bowiem obowiązek uzyskania pozwolenia konserwatorskiego, o którym mowa w art. 36 ust. 1 pkt 1 tej ustawy.
\end{abstract}

\section{Wprowadzenie do zagadnienia}

Glosowany wyrok dotyczy problematycznego zagadnienia decyzji nakazującej przywrócenie zabytku do stanu poprzedniego albo zobowiązującej do doprowadzenia zabytku do jak najlepszego stanu we wskazany sposób i w określonym terminie w sytuacji, kiedy zabytek nieruchomy został wpisany do rejestru zabytków po wydaniu decyzji o pozwolenie na prowadzenie przy nim robót budowlanych. Rozważeniu podlegają kompetencje organu konserwatorskiego oraz obowiązki podmiotu inwestującego, co $w$ efekcie sprowadza się do zagadnienia sprawowania prawidłowej opieki nad zabytkiem w myśl art. 5 ustawy z dnia 23 lipca 2003 r. o ochronie zabytków i opiece nad zabytkami ${ }^{1}$ (dalej: u.o.z.), który stanowi normę o charakterze bardzo ogólnym². Dotyka to problemu ochrony zabytku, która jest realizowana przez organy administracji publicznej oraz zindy widualizowanej opieki aktualnego dysponenta zabytku, który w sposób należycie staranny postępuje względem zabytku, utrzymuje go w możliwie najlepszej kondycji oraz jak najlepiej wykorzystuje, mając na celu dobro społeczne ${ }^{3}$. W sposób szczególny wyrok Naczelnego Sądu Administracyjnego dotyczy: art. 36 ust. 1 pkt $1 \mathrm{i}$ art. 45 ust. 1 pkt 1 i 2 u.o.z. Poruszane zagadnienie pozostaje $w$ ścisłej korespondencji z nowelizacją ustawy o ochronie zabytków i opiece nad zabytkami, która weszła w życie 9 września 2017 r. W art. 10a ustawodawca wskazał, że od dnia, w którym wszczęto postępowanie w sprawie wpisu zabytku do rejestru, do dnia, kiedy decyzja stanie się ostateczna, przy przedmiotowym obiekcie nie będzie możliwe prowadzenie prac konserwatorskich, restauratorskich, robót budowlanych oraz innych ingerencji, które skutkować by mogły naruszeniem w zakresie jego substancji lub wyglądu.

1 Ustawa z dnia 23 lipca 2003 r. o ochronie zabytków i opiece nad zabytkami, tekst jedn. Dz. U. z 2017 r., poz. 2187 ze zm., Dz. U. z 2018 r. poz. 10.

2 M. Cherka (red.), Ustawa o ochronie zabytków i opiece nad zabytkami. Komentarz, Wolters Kluwer Polska, Warszawa 2010, s. 33.

3 A. Michalak, A. Ginter, Ustawa o ochronie zabytków i opiece nad zabytkami. Komentarz, Wolters Kluwer, Warszawa 2016, s. 84. 
Wskazany zakaz dotyczy również robót budowlanych, które są objęte pozwoleniem na budowę lub zgłoszeniem, a także wszelkich aktywności przy obiekcie, które mają miejsce na mocy innej decyzji. Wyjątkiem od tego są zabytki służące obronności i bezpieczeństwu państwa ${ }^{4}$. Jak widać, ochrona zabytku trwa od dnia wszczęcia postępowania o wpis do rejestru.

\section{Glosa}

Należy przyznać słuszność Naczelnemu Sądowi Administracyjnemu, który w omawianym orzeczeniu wskazał na szczególny zakres działań konserwatorskich w zakresie ochrony zabytków, jako dóbr o szczególnym znaczeniu, w sytuacji styku różnych płaszczyzn prawa. Orzeczenie dotyczy problemu działań dysponenta przy obiekcie, który z biegiem czasu zostaje wpisany do rejestru zabytków. Już w obrębie systemu prawa rzymskiego znalazły się wskazania co do możliwości ograniczania własności z uwagi na względy społeczne. Koncepcja ta rodziła dużo kontrowersji z uwagi na problematyczne zestawienie treści prawa własności i zakres jego ograniczeń 5 . Interesujące spojrzenie doktryny na prawo własności reprezentował funkcjonalizm własności, zgodnie z którym jest ona ściśle związana z funkcją społeczną. Tu upatrywać należało źródeł praw oraz obowiązków i to użyteczności w tym rozumieniu powinny być podporządkowanie działania właściciela ${ }^{6}$. Konstytucja Rzeczypospolitej Polskiej w art. 21 i $46^{7}$ w sposób szczególny zaznaczyła konieczność ochrony własności, a co za tym idzie, wszelkie formy ingerowania administracji publicznej w prawo własności nieruchomości nabrały wyjątkowego charakteru. Ich ograniczony zakres pozostaje do dziś w związku z ustrojem gospodarki rynkowej, jednak i w tej sytuacji pewne okoliczności stanowią dla nich dostateczne uzasadnienie ${ }^{8}$.

W polskim systemie ochrony dziedzictwa kulturowego kluczowe znaczenie mają trzy pojęcia charakteryzujące działania podmiotów wobec zasobu zabytkowego: „strzeżenie”, „ochrona” $i$ „opieka”. Pierwsze z nich odnosi się do zadań po stronie Rzeczypospolitej i jest wymieniane wśród podstawowych zadań aparatu państwowego, drugie dotyczy organów administracji publicznej, ostatnie zaś występuje

\footnotetext{
4 A. Puszkarska, Zmiany w ustawie o ochronie zabytków, „Rzeczpospolita”, 9.09.2017, http://www.rp.pl/ Ustroj-i-kompetencje/309099998-Zmiany-w-ustawie-o-ochronie-zabytkow.html [dostęp: 4.07.2018]. Por. też: projekt ustawy o zmianie ustawy o ochronie zabytków i opiece nad zabytkami oraz niektórych innych ustaw, 28.02.2017, https://www.premier.gov.pl/wydarzenia/decyzje-rzadu/projekt-ustawy-o-zmianie-ustawy-o-ochronie-zabytkow-i-opiece-nad-zabytkam-0.html [dostęp: 4.07.2018].

5 B. Ruszkiewicz, Wpływ decyzji wojewódzkiego konserwatora zabytków na wykonywanie własności zabytków nieruchomych, w: K. Zeidler (red.), Prawo ochrony zabytków, Wolters Kluwer, Wydawnictwo Uniwersytetu Gdańskiego, Warszawa - Gdańsk 2014, s. 320.

6 Ibidem, s. 322.

7 Konstytucja Rzeczypospolitej Polskiej z dnia 2 kwietnia 1997 r., Dz. U. z 2009 r. Nr 114, poz. 946 ze zm.

8 B. Ruszkiewicz, op. cit., s. 322.
} 
Kompetencje organu konserwatorskiego do wydania decyzji... The Competence of a Conservation Body to Issue a Construction Permit...

w kontekście działań właścicieli i posiadaczy obiektów?. Jakkolwiek każdy zabytek w znaczeniu materialnym powinien stanowić przedmiot opieki ${ }^{10}$, znaczący wpływ na prawa właściciela do dysponowania i używania nieruchomości konstytuuje wpis do rejestru zabytków, albowiem z jego momentem podmiot może doświadczać znacznych ograniczeń ${ }^{11}$. Ingerencja taka może być daleko idąca i przybierać nawet postać wywłaszczenia na mocy ustawy o ochronie zabytków i opiece nad zabytkami. Obiekt od momentu wpisu do rejestru, ze względu na szczególną wartość, należy postrzegać nie tylko jako dobro prywatne dysponenta. Problemu tego dotyka glosowane orzeczenie. Dotkliwość i waga konsekwencji wpisu została zauważona przez Naczelny Sąd Administracyjny, który już w orzeczeniu z dnia 21 października 1999 r. ${ }^{12}$ wskazał, że decyzję o wpisie do rejestru należy poprzedzić dokładną oceną jego zasadności. Konieczna jest też ocena z perspektywy zasady nienaruszania sensu prawa własności. Zgodnie z art. 64 ust. 3 Konstytucji, uzasadnieniem wspomnianego powinna być niepodlegająca zakwestionowaniu wartość zabytku ${ }^{13}$. Jest to zasadne zwłaszcza wobec faktu, że wykreślenie nieruchomości z rejestru może mieć miejsce tylko w wyjątkowych przypadkach na mocy art. 13 u.o.z. (dewastacja zabytku powiązana z pozbawieniem go wartości historycznej, artystycznej lub naukowej albo przypadek, gdy podstawy do wydania decyzji o wpisie w zakresie wartości zabytku nie znajdują aktualnego potwierdzenia naukowego) ${ }^{14}$ i art. 132 Kodeksu postępowania administracyjnego ${ }^{15}$. Warto dodać, że skreślenie z rejestru ze względu na dewastację zabytku oraz brak potwierdzenia wartości, która stanowiła podstawę decyzji o wpisie, wymagają wykazania dodatkowego materiału dowodowego, jest to więc postępowanie z reguły skomplikowane ${ }^{16}$.

Naczelny Sąd Administracyjny w glosowanym wyroku z dnia 18 października 2016 r. ${ }^{17}$ wyraźnie i prawidłowo wskazał skutki wpisu do rejestru zabytku, na-

\footnotetext{
9 J. Sługocki, Opieka nad zabytkiem nieruchomym. Problemy administracyjnoprawne, wyd. 2, Wolters Kluwer Polska, Warszawa 2017, s. 62-65.

10 A. Michalak, A. Ginter, op. cit., s. 84.

11 S. Jarosz-Żukowska, Konstytucyjna zasada ochrony własności, Zakamycze, Kraków 2003, s. 204, cyt. za:

B. Ruszkiewicz, op. cit., s. 323.

12 Wyrok Naczelnego Sądu Administracyjnego z dnia 21 października 1999 r., sygn. akt I SA 233/99, http://orzeczenia.nsa.gov.pl/doc/FE585C3BB3 [dostęp: 4.07.2018].

13 Ibidem; wyrok Naczelnego Sądu Administracyjnego z dnia 25 października 1991 r., sygn. akt I SA 948/91, http://orzeczenia.nsa.gov.pl/doc/DE592972B8 [dostęp: 4.07.2018]; analizę wartości obiektu opierano w tym wypadku na art. 5 ustawy z dnia 15 lutego 1962 r. o ochronie dóbr kultury, Dz. U. z 1962 r. $\mathrm{Nr} 10$, poz. 48.

14 S. Jarosz-Żukowska, op. cit., s. 204, cyt. za: B. Ruszkiewicz, op. cit., s. 325.

15 Ustawa z dnia 14 czerwca 1960 r. Kodeks postępowania administracyjnego, Dz. U. z 2017 r., poz. 1257 ze zm.

16 K.Zalasińska, K. Zeidler, Wykład prawa ochrony zabytków, Wolters Kluwer, Wydawnictwo Uniwersytetu Gdańskiego, Warszawa - Gdańsk 2015, s. 92.

17 Wyrok Naczelnego Sądu Administracyjnego z dnia 18 października 2016 r., sygn. akt II OSK 3/15, http://orzeczenia.nsa.gov.pl/doc/42AE8BCB88 [dostęp: 2.07.2018].
} 


\section{ORZECZNICTWO}

wet gdy miał on miejsce po wydaniu decyzji o pozwolenie na prowadzenie robót budowlanych przy nieruchomości. W tezie omawianego orzeczenia zauważono, że data wpisu konstytuuje po stronie inwestora obowiązek uzyskania pozwolenia konserwatorskiego, z czym należy się zgodzić. Wobec tego zasadne stało się stwierdzenie, że w tej sytuacji organ konserwatorski miał kompetencję do wydania decyzji na mocy art. 45 ust. 1 u.o.z.

Sąd, co cenne, zwrócił też uwagę na problem braku dokładnej analizy problematycznego zagadnienia w uzasadnienia decyzji ze strony organów konserwatorskich. Rozważając skutki wpisu do rejestru zabytków, warto podkreślić, że jednym z bardziej niedookreślonych zagadnień stosowania przepisów prawa ochrony zabytków jest brak jasnych i wyraźnych kryteriów wartościowania obiektów zabytkowych. Zbyt generalne wytyczne w tym zakresie rażą tym bardziej, że dotyczą istotnych spraw z zakresu prawa własności, a to właśnie w obrębie prawa ochrony zabytków reglamentacja własności jest szczególnie odczuwalna ${ }^{18}$. Uznaniowość decyzji organów konserwatorskich stanowi jedną z najczęstszych przyczyn krytyki ich funkcjonowania ${ }^{19}$. Jakkolwiek znaczna liczba pojęć niedookreślonych jest niebezpieczna w procesie stosowania prawa, to wartościowanie jest konieczne, zwłaszcza jeżeli chodzi o specyfikę prawa ochrony zabytków.

Rozwiązania problemu należy upatrywać w prawidłowych uwarunkowaniach ustrojowych organów. Kontrowersje wokół uznaniowości wymuszają szczególną staranność w wykazaniu racji zajmowanego stanowiska. Należy przyznać słuszność sądowi w aspekcie niedostatecznego rozważenia wszelkich istotnych okoliczności faktycznych w sprawie oraz braku wystarczającego uzasadnienia wskazującego, że demontaż zadaszenia jest jedynym skutecznym środkiem zachowania wartości zabytkowych w tym wypadku. Ponadto sąd zauważył, że naruszono tu zasadę proporcjonalności, w myśl której należałoby szczegółowo przeanalizować i wykazać, czemu inne, być możne związane z mniejszą ingerencją, czynności nie mogą zostać podjęte.

Analiza glosowanego orzeczenia pozwala w szerszej perspektywie zauważyć, jak niezbędna jest należyta staranność w działaniach po stronie organów. System ochrony, który działa głównie poprzez zakazy i nakazy, nie zawsze służy właściwej ochronie nieruchomości zabytkowej. Warto dodać, że postulowaną przez doktrynę zmianą miałoby być nawet postrzeganie ochrony zabytków w kategoriach perswazyjnych, a nie nakazów i zakazów. Tym bardziej istotna byłaby, zauważona przez sąd w glosowanym orzeczeniu, wnikliwa analiza stanu faktycznego i dokładne uzasadnianie decyzji. Korelacja ochrony i opieki, zrozumienie przez adresatów zasadności

18 J. Pruszyński, Własność dzieł sztuki i zabytków - dylematy restytucji, w: I. Skrzydło-Niżnik, P. Dobosz, D. Dąbek, M. Smaga (red.), Instytucje współczesnego prawa administracyjnego. Księga jubileuszowa Profesora zw. dra hab. Józefa Filipka, Wydawnictwo Uniwersytetu Jagiellońskiego, Kraków 2001, s. 587-599, cyt. za: B. Ruszkiewicz, op. cit., s. 327.

19 J. Sługocki, op. cit., s. 276-277. 
Kompetencje organu konserwatorskiego do wydania decyzji... The Competence of a Conservation Body to Issue a Construction Permit...

działań konserwatorskich, charakter systemowy tej relacji mógłby, z jednoczesną obserwacją jej funkcjonowania i zachowaniem dużej ostrożności, przynieść korzyści $^{20}$. Jedną z proponowanych dróg poprawy działania służby ochrony zabytków w Polsce jest też przechodzenie od modelu władczego do partycypacyjnego w zakresie ochrony dziedzictwa kultury. Postulat ten w obliczu tendencji centralizacji uprawnień stawia przed administracją publiczną szereg wyzwań ${ }^{21}$.

Rozważany w glosowanym wyroku problem pokazuje dotkliwe skutki prawne dysponowania zabytkiem. Często nie idą one w parze z uprawnieniami po stronie dostosowującego się do norm właściciela zabytku, zwłaszcza jeżeli chodzi o korzyści $^{22}$. Opieka nad zabytkiem generuje nierzadko znaczne nakłady finansowe dysponenta zabytku. Dolegliwości natury ekonomicznej nie mogą jednak stanowić przyczyny odstąpienia od aktywności, mającej na celu zachowanie substancji i wartości zabytkowej obiektu w sytuacji zagrożenia niszczeniem, co zauważył Wojewódzki Sąd Administracyjny w Warszawie w uzasadnieniu wyroku z dnia 23 kwietnia 2009 r. ${ }^{23}$ oraz w uzasadnieniu wyroku z dnia 29 maja 2008 r..$^{24}$

Specyfika działań przy nieruchomości wymusza powstanie szczególnej płaszczyzny współwystępowania prawa ochrony zabytków i prawa budowlanego, na co zwraca uwagę Naczelny Sąd Administracyjny w uzasadnieniu komentowanego orzeczenia. Postępowanie organów konserwatorskich ma autonomiczny charakter. Słusznie zauważono, że specyfika działań służb sprawia, że legislator nadał im kompetencje również względem obiektów, które nie są objęte formami ochrony w myśl art. 7 u.o.z., czego świadectwem jest wspomniany w uzasadnieniu wyroku art. 46 ust. 1 u.o.z., gdzie znajduje się umocowanie do wstrzymania w szczególnych okolicznościach prac lub robót budowlanych przy zabytku, który nie jest wpisany do rejestru. Działania organów konserwatorskich nie pozostają w zależności od legalności prac budowlanych w myśl Prawa budowlanego ${ }^{25}$. Sąd prawidłowo zaznaczył, że oba porządki różni przede wszystkim cel, którym w przypadku ochrony zabytków jest niedopuszczenie do degradacji wartości zabytkowej. Art. 39 ust. 1 Prawa budowlanego $\mathrm{w}$ zestawieniu $\mathrm{z}$ art. 36 ust. 1 pkt 1 u.o.z. nie stanowi wykluczenia dla działań konserwatora zabytków w sytuacji, której dotyczył wyrok ${ }^{26}$.

\footnotetext{
$20 \quad$ Ibidem, s. 89.

21 K. Zeidler, O właściwy kształt służby ochrony zabytków w Polsce. Postulaty de lege ferenda, w: idem, Zabytki. Prawo i praktyka, Wydawnictwo Uniwersytetu Gdańskiego, Wolters Kluwer, Gdańsk - Warszawa 2017, s. 54-55.

22 Zob. szerzej: B. Ruszkiewicz, s. 327.

23 Wyrok Wojewódzkiego Sądu Administracyjnego w Warszawie z dnia 23 kwietnia 2009 r., sygn. akt I SA/Wa 48/09, http://orzeczenia.nsa.gov.pl/doc/B3DB8693AF [dostęp: 2.07.2018].

24 Wyrok Wojewódzkiego Sądu Administracyjnego w Warszawie z dnia 29 maja 2008 r., sygn. akt ISA/Wa 55/08, http://orzeczenia.nsa.gov.pl/doc/F3E1A0B84E [dostęp: 28.06.2018].

25 Ustawa z dnia 7 lipca 1994 r. Prawo budowlane, Dz. U. z 2000 r. Nr 106, poz. 1126 ze zm.

26 Wyrok Naczelnego Sądu Administracyjnego z dnia 18 października 2016 r., sygn. akt II OSK 3/15, http://orzeczenia.nsa.gov.pl/doc/42AE8BCB88 [dostęp: 2.07.2018].
} 
Zgodzić należy się z tym, że Prawo budowlane i ochrona zabytków nie pozostają tu w sprzeczności, tylko równolegle regulują dwie płaszczyzny ogólnego porządku prawnego.

W wyroku Naczelnego Sądu Administracyjnego z dnia 2 września 2006 r. $^{27}$ wskazano m.in., że ochrona zabytków, czyli dóbr, które są otoczone ochroną konstytucyjną, sytuuje się przed prawem właściciela do zabudowy swojej nieruchomości w myśl przepisów ustawy Prawo budowlane. Nadrzędnym ratio decyzji wojewódzkiego konserwatora zabytków jest wyłącznie wyznaczenie treści i granic ochrony prawa własności w ogólnym interesie, także samych właścicieli. Przy tym nie pozbawiają one prawa korzystania, czerpania pożytków i rozporządzania rzeczą ${ }^{28}$. Rolą organów, które zajmują się ochroną zabytków, jest zapobieganie wszystkim działaniom, które mogłyby negatywnie wpłynąć na utrzymanie obiektu zabytkowego, czynić jego zachowanie niemożliwym oraz degradować jego walory zabytkowe $^{29}$. Naczelny Sąd Administracyjny w uzasadnieniu w sposób właściwy wskazał, że zadaniem ustawowym organów konserwatorskich jest działanie ukierunkowane na zachowanie dziedzictwa narodowego, nie był zatem zasadny zarzut naruszenia art. 45 ust. 1 pkt 1 u.o.z.

Katalog działań, które wymagają pozwolenia wojewódzkiego konserwatora zabytków, zawiera art. 36 u.o.z., którego poprzednikiem był art. 27 ust. 1 poprzednio obowiązującej ustawy o ochronie dóbr kultury ${ }^{30}$. Ściśle koresponduje z nim rozporządzenie Ministra Kultury i Dziedzictwa Narodowego z dnia 22 czerwca 2017 r. w sprawie prowadzenia prac konserwatorskich, prac restauratorskich i badań konserwatorskich przy zabytku wpisanym do rejestru zabytków albo na Listę Skarbów Dziedzictwa oraz robót budowlanych, badań architektonicznych i innych działań przy zabytku wpisanym do rejestru zabytków, a także badań archeologicznych i poszukiwań zabytków ${ }^{31}$, gdzie znajdują się informacje m.in. na temat trybu wydawania pozwoleń. Glosowane orzeczenie wskazuje na art. 36 u.o.z. Szczególne znaczenie w rozważeniu przedmiotowej sprawy ma wyrok Naczelnego Sądu Administracyjnego z dnia 20 czerwca 2012 r. ${ }^{32} \mathrm{~W}$ jego uzasadnieniu wskazano, że

27 Wyrok Naczelnego Sądu Administracyjnego z dnia 9 lutego 2006 r., sygn. akt II OSK 494/05, http:// orzeczenia.nsa.gov.pl/doc/8F6835175F [dostęp: 20.06.2018].

28 B. Ruszkiewicz, op. cit., s. 321.

29 A. Michalak, A. Ginter, op. cit., s. 201; wyrok Wojewódzkiego Sądu Administracyjnego w Warszawie z dnia 15 grudnia 2006 r., sygn. akt ISA/Wa 1572/06, LEX nr 320593.

30 Ustawa z dnia 15 lutego 1962 r. o ochronie dóbr kultury, tekst jedn. Dz. U. z 1999 r. Nr 98, poz. 1150 z późn. zm.

31 Rozporządzenie Ministra Kultury i Dziedzictwa Narodowego z dnia 22 czerwca 2017 r. w sprawie prowadzenia prac konserwatorskich, prac restauratorskich i badań konserwatorskich przy zabytku wpisanym do rejestru zabytków albo na Listę Skarbów Dziedzictwa oraz robót budowlanych, badań architektonicznych i innych działań przy zabytku wpisanym do rejestru zabytków, a także badań archeologicznych i poszukiwań zabytków, Dz. U. z 2017 r., poz. 1265. 
Kompetencje organu konserwatorskiego do wydania decyzji... The Competence of a Conservation Body to Issue a Construction Permit...

podmiot inwestujący, który zgodnie z prawem chce dokonać prac budowlanych przy zabytku położonym na obszarze wpisanym do rejestru zabytków, jest zobligowany do przedstawienia decyzji organu konserwatorskiego. Tym bardziej konieczne będzie to zatem w sytuacji legalizacji robót budowlanych, włącznie z pracami, które mają doprowadzić te czynności, które zostały już wykonane, do prawidłowego względem prawa stanu. Decyzji nie można zastąpić pismem, które zawiera stanowisko organu ${ }^{33}$. Dawniej, jeszcze w czasie obowiązywania ustawy o ochronie dóbr kultury, rozstrzygnięciu temu nadawano różny kształt graficzny i prawny, jednak z czasem wykształciła się jednolita linia orzecznicza, aprobująca wyłącznie formę decyzji administracyjnej ${ }^{34}$. Kiedy dochodzi do sytuacji, gdy wpis nieruchomości miał miejsce po zainicjowaniu procesu inwestycyjnego, niezbędne będzie uzyskanie pozwolenia w myśl art. 36 u.o.z. ${ }^{35}$ Warto przy tym dodać, że decyzje na mocy art. 36 ust. 1 pkt 1 u.o.z. wydaje się na mocy tzw. uznania administracyjnego, w związku z czym niebagatelną rolę odgrywa dokładne ustalenie wpływu inwestycji na walory zabytku ${ }^{36}$. Decyzja taka podlega ocenie sądu administracyjnego od strony formalnoprawnej, również argumentacja kontrolowana jest pod względem spójności w rozstrzygnięciu konkretnej sprawy ${ }^{37}$. Wobec tego odmienne stanowisko przedstawił Naczelny Sąd Administracyjny w tezie wyroku z dnia 26 lipca $2012 r^{38}$, albowiem znajdujemy tu wskazanie, że pozwolenie na wykonanie prac na mocy art. 36 ust. 1 pkt 11 u.o.z. nie leży w gestii swobodnego uznania wojewódzkiego konserwatora zabytków.

Zgodnie z art. 45 u.o.z., w sytuacji wykonania prac bez pozwolenia organ wydaje decyzję, wybierając jedną z dwóch możliwości zaproponowanych przez ustawodawcę. Naczelny Sąd Administracyjny w sposób właściwy dokonał analizy i stwierdził, że w omawianej sprawie decyzje administracyjne były niejednoznaczne i sprzeczne z zasadą budowania zaufania do organów administracji publicznej. Organ odwoławczy zamiennie stosował podstawę prawną utrzymania w mocy nakazu usunięcia problematycznego elementu. Organ konserwatorski przywołał w swoim rozstrzygnięciu art. 45 ust. 1 pkt 1 u.o.z., natomiast w uzasadnieniu odniósł się do art. 45 ust. 1 pkt 2 u.o.z. Minister Kultury i Dziedzictwa Narodowego

33 A. Michalak, A. Ginter, op. cit., s. 202; zob. wyrok Naczelnego Sądu Administracyjnego z dnia 20 czerwca 2012 r., sygn. akt II OSK 524/11, http://orzeczenia.nsa.gov.pl/doc/344951B376 [dostęp: 4.07.2018].

34 M. Cherka (red.), op. cit., s. 172-173.

35 D. Chaciński, Zakres ochrony zabytków nieruchomych na tle wybranych orzeczeń WSA w Warszawie, „Zeszyty Naukowe Sądownictwa Administracyjnego" 2012, nr 1, s. 18-30, cyt. za: A. Michalak, A. Ginter, op. cit., s. 201.

36 A. Michalak, A. Ginter, op. cit., s. 203.

37 Ibidem, s. 204, autorzy przywołują wyrok Wojewódzkiego Sądu Administracyjnego w Warszawie z dnia 19 maja 2014 r., sygn. akt VII SA/Wa 254/14, http://orzeczenia.nsa.gov.pl/doc/6A29C35A47 [dostęp: 4.07.2018] i inne.

38 Wyrok Naczelnego Sądu Administracyjnego z dnia 26 lipca 2012 r., sygn. akt II OSK 756/11, http:// orzeczenia.nsa.gov.pl/doc/32741923DF [dostęp: 4.07.2018]. 


\title{
ORZECZNICTWO
}

\author{
Dominika Kostrzewa
}

z kolei najpierw oparł się na art. 45 ust. 1 pkt 2 u.o.z., w uzasadnieniu zaś pojawiły się przesłanki stosowania art. 41 ust. 1 pkt 1 u.o.z.

Omawiany art. 45 u.o.z. w opinii doktryny jest problematyczny, gdyż nie stanowi możliwości legalizacji działań, które nie doprowadziły do niekorzystnych zmian w wartości obiektu ${ }^{39} . Z$ drugiej strony organ nie może również na podstawie art. 45 ust. 1 pkt 2 u.o.z. zastosować nakazu usunięcia obiektu w postaci jego rozbiórki ${ }^{40}$. Gdy zaistnieje sytuacja wykonania przy zabytku prac, które nie są zgodne z zakresem i warunkami wskazanymi w pozwoleniu, wojewódzki konserwator zabytków powinien dokładnie wskazać, wyjaśnić i uzasadnić, jaką postać mają nieprawidłowości oraz jakie generują zagrożenia ${ }^{41}$. Przesłanki rozstrzygnięcia są uznaniowe. Ustalenie ich skutkuje tym, że rozstrzygnięcie ma charakter związany ${ }^{42}$.

Podsumowując, glosowane orzeczenie stanowi przykład wielowątkowego zagadnienia, które pozostaje w ścisłym związku z aktualnymi działaniami legislacyjnymi. Sytuacja przywrócenia zabytku nieruchomego do stanu poprzedniego albo zobowiązania do doprowadzenia go do jak najlepszego stanu we wskazany sposób i w określonym terminie w sytuacji, gdy został wpisany do rejestru zabytków po wydaniu decyzji o pozwolenie na prowadzenie przy nim robót budowlanych, ukazała kompetencje organów konserwatorskich, charakter ich postępowania oraz prawa i obowiązki dysponenta obiektu, umożliwiając wnikliwą analizę problematycznej kwestii. Naczelny Sąd Administracyjny dokonał jej w sposób prawidłowy, rozważając usprawiedliwione podstawy skargi kasacyjnej oraz należycie wskazując, które z zarzutów są zasadne.

\section{Bibliografia}

Chaciński D., Zakres ochrony zabytków nieruchomych na tle wybranych orzeczeń WSA w Warszawie, „Zeszyty Naukowe Sądownictwa Administracyjnego” 2012, nr 1.

Cherka M. (red.), Ustawa o ochronie zabytków i opiece nad zabytkami. Komentarz, Wolters Kluwer Polska, Warszawa 2010.

Jarosz-Żukowska S., Konstytucyjna zasada ochrony własności, Zakamycze, Kraków 2003.

Konstytucja Rzeczypospolitej Polskiej z dnia 2 kwietnia 1997 r., Dz. U. z 2009 r. Nr 114, poz. 946 ze zm.

Michalak A., Ginter A., Ustawa o ochronie zabytków i opiece nad zabytkami. Komentarz, Wolters Kluwer, Warszawa 2016.

39 E. Pabisiak, Nadzór konserwatorski - propozycje zmian ustawy o ochronie zabytków i opiece nad zabytkami, w: K. Zeidler (red.), Prawo ochrony zabytków, Wolters Kluwer, Wydawnictwo Uniwersytetu Gdańskiego, Warszawa - Gdańsk 2014, s. 349.

40 A. Michalak, A. Ginter, op. cit., s. 295; wyrok Naczelnego Sądu Administracyjnego z dnia 8 stycznia 2013, sygn. akt II OSK 1635/11, http://orzeczenia.nsa.gov.pl/doc/657E8EF329 [dostęp: 5.07.2018].

41 Ibidem, s. 295.

42 A. Michalak, A. Ginter, op. cit., s. 295; wyrok Wojewódzkiego Sądu Administracyjnego w Warszawie z dnia 15 lutego 2013 r., sygn. akt I SA/Wa 386/12, http://orzeczenia.nsa.gov.pl/doc/3A57F1DC8F [dostęp: 4.07.2018]. 
Kompetencje organu konserwatorskiego do wydania decyzji... The Competence of a Conservation Body to Issue a Construction Permit...

Pabisiak E., Nadzór konserwatorski - propozycje zmian ustawy o ochronie zabytków i opiece nad zabytkami, w: K. Zeidler (red.), Prawo ochrony zabytków, Wolters Kluwer, Wydawnictwo Uniwersytetu Gdańskiego, Warszawa - Gdańsk 2014.

Projekt ustawy o zmianie ustawy o ochronie zabytków i opiece nad zabytkami oraz niektórych innych ustaw, 28.02.2017, https://www.premier.gov.pl/wydarzenia/decyzje-rzadu/projekt-ustawy-o-zmianie-ustawy-o-ochronie-zabytkow-i-opiece-nad-zabytkam-0.html [dostęp: 4.07.2018].

Pruszyński J., Własność dzieł sztuki i zabytków - dylematy restytucji, w: I. Skrzydło-Niżnik, P. Dobosz, D. Dąbek, M. Smaga (red.), Instytucje współczesnego prawa administracyjnego. Księga jubileuszowa Profesora zw. dra hab. Józefa Filipka, Wydawnictwo Uniwersytetu Jagiellońskiego, Kraków 2001.

Puszkarska A., Zmiany w ustawie o ochronie zabytków, „Rzeczpospolita”, 9.09.2017, http:// www.rp.pl/Ustroj-i-kompetencje/309099998-Zmiany-w-ustawie-o-ochronie-zabytkow.html [dostęp: 4.07.2018].

Rozporządzenie Ministra Kultury i Dziedzictwa Narodowego z dnia 22 czerwca 2017 r. w sprawie prowadzenia prac konserwatorskich, prac restauratorskich i badań konserwatorskich przy zabytku wpisanym do rejestru zabytków albo na Listę Skarbów Dziedzictwa oraz robót budowlanych, badań architektonicznych i innych działań przy zabytku wpisanym do rejestru zabytków, a także badań archeologicznych i poszukiwań zabytków, Dz. U. z 2017 r., poz. 1265.

Ruszkiewicz B., Wpływ decyzji wojewódzkiego konserwatora zabytków na wykonywanie własności zabytków nieruchomych, w: K. Zeidler (red.), Prawo ochrony zabytków, Wolters Kluwer, Wydawnictwo Uniwersytetu Gdańskiego, Warszawa - Gdańsk 2014.

Sługocki J., Opieka nad zabytkiem nieruchomym. Problemy administracyjnoprawne, wyd. 2, Wolters Kluwer Polska, Warszawa 2017.

Ustawa z dnia 14 czerwca 1960 r. Kodeks postępowania administracyjnego, Dz. U. z 2017 r., poz. 1257 ze zm.

Ustawa z dnia 15 lutego 1962 r. o ochronie dóbr kultury, Dz. U. z 1962 r. Nr 10, poz. 48, tekst jedn. Dz. U. z 1999 r. Nr 98, poz. 1150 z późn. zm.

Ustawa z dnia 7 lipca 1994 r. Prawo budowlane, Dz. U. z 2000 r. Nr 106, poz. 1126 ze zm.

Ustawa z dnia 23 lipca 2003 r. o ochronie zabytków i opiece nad zabytkami, tekst jedn. Dz. U. z 2017 r., poz. 2187 ze zm., Dz. U. z 2018 r. poz. 10.

Wyrok Naczelnego Sądu Administracyjnego z dnia 25 października 1991 r., sygn. akt I SA 948/91, http://orzeczenia.nsa.gov.pl/doc/DE592972B8 [dostęp: 4.07.2018].

Wyrok Naczelnego Sądu Administracyjnego z dnia 21 października 1999 r., sygn. akt I SA 233/99, http://orzeczenia.nsa.gov.pl/doc/FE585C3BB3 [dostęp: 4.07.2018].

Wyrok Naczelnego Sądu Administracyjnego z dnia 9 lutego 2006 r., sygn. akt II OSK 494/05, http://orzeczenia.nsa.gov.pl/doc/8F6835175F [dostęp: 20.06.2018].

Wyrok Naczelnego Sądu Administracyjnego z dnia 20 czerwca 2012 r., sygn. akt II OSK 524/11, http://orzeczenia.nsa.gov.pl/doc/344951B376 [dostęp: 4.07.2018].

Wyrok Naczelnego Sądu Administracyjnego z dnia 26 lipca 2012 r., sygn. akt II OSK 756/11, http://orzeczenia.nsa.gov.pl/doc/32741923DF [dostęp: 4.07.2018].

Wyrok Naczelnego Sądu Administracyjnego z dnia 8 stycznia 2013, sygn. akt II OSK 1635/11, http://orzeczenia.nsa.gov.pl/doc/657E8EF329 [dostęp: 5.07.2018]. 


\title{
ORZECZNICTWO
}

\author{
Dominika Kostrzewa
}

Wyrok Naczelnego Sądu Administracyjnego z dnia 18 października 2016 r., sygn. akt II OSK 3/15, http://orzeczenia.nsa.gov.pl/doc/42AE8BCB88 [dostęp: 2.07.2018].

Wyrok Wojewódzkiego Sądu Administracyjnego w Warszawie z dnia 15 grudnia 2006 r., sygn. akt ISA/Wa 1572/06, LEX nr 320593.

Wyrok Wojewódzkiego Sądu Administracyjnego w Warszawie z dnia 29 maja 2008 r., sygn. akt I SA/Wa 55/08, http://orzeczenia.nsa.gov.pl/doc/F3E1A0B84E [dostęp: 28.06.2018].

Wyrok Wojewódzkiego Sądu Administracyjnego w Warszawie z dnia 23 kwietnia 2009 r., sygn. akt I SA/Wa 48/09, http://orzeczenia.nsa.gov.pl/doc/B3DB8693AF [dostęp: 2.07.2018].

Wyrok Wojewódzkiego Sądu Administracyjnego w Warszawie z dnia 15 lutego 2013 r., sygn. akt I SA/Wa 386/12, http://orzeczenia.nsa.gov.pl/doc/3A57F1DC8F [dostęp: 4.07.2018].

Wyrok Wojewódzkiego Sądu Administracyjnego w Warszawie z dnia 19 maja 2014 r., sygn. akt VII SA/Wa 254/14, http://orzeczenia.nsa.gov.pl/doc/6A29C35A47 [dostęp: 4.07.2018].

Zalasińska K., Zeidler K., Wykład prawa ochrony zabytków, Wolters Kluwer, Wydawnictwo Uniwersytetu Gdańskiego, Warszawa - Gdańsk 2015.

Zeidler K., O właściwy kształt służby ochrony zabytków w Polsce. Postulaty de lege ferenda, w: K. Zeidler, Zabytki. Prawo i praktyka, Wydawnictwo Uniwersytetu Gdańskiego, Wolters Kluwer, Gdańsk - Warszawa 2017. 